\title{
Notes from young physician candidates on the primary health care system
}

\author{
Kubilay Kaymaza, Esra Bilira \\ a Medical student, Koç University, School of Medicine, İstanbul, Turkey
}

\begin{abstract}
In this paper, we aim to share our experiences and observations made during the obligatory primary care internship at a Family Health Center and a Community Health Center. We noted our experiences in a systematic manner using the key characteristics of good primary care provision defined in World Health Organization Primary Care Evaluation Tool (access to the services, comprehensiveness, continuity and coordination of care). We also pointed out the importance of a medical education curriculum for Primary Health Care (PHC) focusing on the potential struggles of the new graduates. Eventually, we realized that PHC is an underestimated topic within medical education and stronger PHC in Turkey would greatly benefit the patients and the system. Demographic features of the district in which we have worked had both its unique advantages and disadvantages. We observed that most of the problems encountered during the provision of PHC in these centers were due to flawed coordination among primary and other level providers, suboptimal work environment and conditions including high number of patients per primary care physician, underestimation of certain preventive services such as family planning and a need for better health information systems. We believe that undergraduate training at PHC level should be emphasized and undertaken through an effective partnership between stakeholders.
\end{abstract}

Keywords: Primary health care, medical student, internship, medical education, Turkey

Corresponding to: Kubilay Kaymaz, Koç Üniversitesi Tıp Fakültesi, Rumelifeneri Yolu, 34450, Sarıyer, İstanbul, Türkiye. Tlf: 02123381000, Eposta: kkaymaz@ku.edu.tr

Copyright holder Turkish Journal of Public Health

This work is licensed under a Creative Commons Attribution-NonCommercial 4.0 International License. (cc) EY-No This is an open Access article which can be used if cited properly. 


\section{Genç doktor adaylarından temel sağlık hizmetleri üzerine notlar}

\section{$\ddot{0} \mathbf{z}$}

Bu yazıda, Aile Sağlığı Merkezi ve Toplum Sağlığı Merkezi'nde zorunlu temel sağlık hizmetleri stajımız sırasında edindiğimiz tecrübe ve gözlemlerimizi paylaşmayı amaçlıyoruz. Dünya Sağlık Örgütü Birinci Basamak Değerlendirme Aracı'nda tanımlanan iyi bir birinci basamak sağlık hizmetleri sunumunun temel özelliklerini (hizmete erişim, kapsamlılık, süreklilik ve bakımın koordinasyonu) kullanarak tecrübemizi sistematik bir şekilde not ettik. Ayrıca yeni mezunların potansiyel sorunlarına odaklanarak Temel Sağlık Hizmetleri (TSH) için tıp eğitimi müfredatının önemine de dikkat çektik. Nihayetinde TSH'nin tıp eğitiminde ihmal edilen bir konu olduğunu ve Türkiye'de daha güçlü bir TSH'nin hastalara ve sisteme büyük fayda sağlayacağını gördük. Çalıştığımız ilçenin demografik özelliklerinin kendine özgü avantaj ve dezavantajları vardı. Bu merkezlerde TSH sunumu sırasında karşılaşılan sorunların çoğunun, birinci basamak ve diğer seviye sağlayıcılar arasındaki kusurlu koordinasyondan, doktor başına düşen yüksek hasta sayısı da dahil uygun olmayan çalışma ortamı ve koşullarından, aile planlaması gibi bazı önleyici hizmetlere gereken önemin verilmemesi ve daha iyi bir sağllk bilgi sistemine ihtiyaç duyulmasından kaynaklandığını gözlemledik. TSH eğitimine ağırlık verilmesi ve bunun paydaşlar arasında etkin bir ortaklık ile yapılması gerektiğine inanıyoruz.

Anahtar kelimeler: Temel sağlık hizmetleri, tıp öğrencisi, intörnlük, tıp eğitimi, Türkiye

\section{Introduction}

In Turkey, final year medical students have obligatory primary care internships for 4-8 weeks. It is a great opportunity for the physician candidates to experience the primary health care (PHC) system. During this internship, students make observations of and participate in the routine activities at a Family Health Center (FHC) and a Community Health Center (CHC).

We have completed our primary care internship in one of the largest districts of Istanbul. In this paper, we critically evaluate our experiences and highlight the opportunities and challenges in the delivery of PHC services by using the World Health Organization Primary Care Evaluation Framework that defines the key characteristics of primary care services (access, comprehensiveness, continuity, and coordination) ${ }^{1}$. Finally, we lay emphasis on the importance of undergraduate training in primary care level in medical schools and its shortcomings.

\section{Access to services}

While the number of doctor visits per person in PHC in Turkey has increased to 2.9 from 1.1 between 2002 and 2017, only a third of all the doctor visits was in PHC in 2017 2. Although access in quantity has seen a rise, while still not enough, the quality of the primary care services provided remains questionable. Overall accessibility of primary care number of medical staff, geographical distribution, affordability, and availability of email/phone consultations...) in Turkey is well behind most European countries ${ }^{3}$.

The FHC had limited waiting space and a high number of waiting patients which might be why patients had the perception of long wait times although the visit time per patient was generally limited to 5-10 minutes. High number of patients pushed family doctors (FDs) to see patients faster which might have caused some preventable harms. Some patients mentioned the influx of immigrants as a cause for their perception of long wait times. Patients often entered the doctor's office before it was their turn and interrupted others' examinations which posed a serious violation of privacy. All 
these might have pushed the population of Esenler with higher socioeconomic levels to secondary/tertiary facilities, while the rest found themselves in frustration in such conditions. Furthermore, the working-class struggled in receiving PHC since their work hours did not match with the schedule of their FDs. The Ministry of Health leaves the FDs flexible in drawing their own office hours which would enable them to work out-of-hours. However, due to security concerns among FDs we observed a lack of motivation to benefit from this opportunity that would relieve to some extent the working class.

The Esenler district is a melting pot with the nearby grand bus station and has a total population of 459.983 , of which $4.93 \%$ are Syrian refugees in $2017^{4}$. We observed that many non-Turkish speakers, especially the Syrian refugees, received health care without proper identification. There is only one refugee health center within 5.227 hectare in Esenler; this might be why we observed many refugee patients in this FHC. Besides geographical access, the language barrier was also a prominent factor in the delivery of PHC services. Although an official call center system is available in Turkey, we saw that it was not promoted, and the patients and FDs handled it in their own ways, which sometimes meant that there was no communication whatsoever between the patient and the provider.

The FHC is equipped with computers and a health information system (aka Aile Hekimliği Bilgi Sistemi-AHBS); however, phone and e-mail consultations were not available, which might be due to low digital literacy among patients and doctors, and an absence of incentives from the government. Better integration of such services in Turkish PHC would ease the access of the elderly and chronically ill patients while allowing patients to save time and money.

\section{Comprehensiveness}

The services provided at FHC are very broad and diverse including the treatment of acute and chronic health conditions, vaccinations, monitoring of infant and pregnant women, and family planning. However, we observed that curative services, such as treating a respiratory infection, mostly dominated the preventive and supportive services (e.g. blood pressure measurement and psychiatric counselling) while certain preventive measures that involve incentives such as child vaccination were given particular attention. We also observed that many patients came only for a repeat prescription, especially people with chronic diseases. Previous studies suggest that this might further hamper the image of PHC 5.Therefore, we believe that a comprehensive approach (a continuum of promotive, preventive, rehabilitative and curative activities) should be encouraged in PHC.

At the FHC, we saw available resources for family planning, such as freeof-charge condoms, oral contraceptives and a dedicated room. However, despite all available facilities, we did not observe regular use of these facilities. We recommend FDs offer family planning consultation as part of their routine service for women of reproductive age in order not to miss any opportunities. Furthermore, we think that it might be useful to organize regular activities at FHC for raising awareness on such topics and building a trustful environment that encourages people to ask for such services.

\section{Continuity and coordination of care}

Continuity and coordination of care are important factors that affect health outcomes. PHC is the entry point to health care and needs to be provided in coordination with other same level providers as well as providers and institutions from other levels. That includes FHC-CHC coordination, and FHC-other level providers.

The referred patients are supposed to come back to see their FDs for having continuous quality care and follow-up, however, we did not observe a sound health care coordination in the process of referrals 
from the FHC. Patients were sometimes sent to other level providers informally without a patient note/registry because of the fact that referral is currently not mandatory in the Turkish health system. This may cause patients to underestimate their conditions and seek care later in time which may cause potential harm. FDs did not take full patient notes in most of the visits due to a large number of patients and suboptimal user interface of AHBS, and medical records were not available for electronic transfer between providers. AHBS was not regarded as a userfriendly tool in ensuring continuity of care or coordination of care between FHC and other level providers. We expect that an improved user-friendly information system would also provide more data on PHC services which would result in better research output.

We saw that there was a lack of coordination between doctors and nurses: nurses were supposed to draw blood only until noon, while doctors were left alone in their offices, seeing patients every 5-10 minutes, without taking vital signs and properly examining the patient. Furthermore, there were 8 doctors and only 2 nurses present most of the time in the FHC we visited.

While seeing patients at FHC, we questioned their tobacco use and realized that there was no educational material present at the FHC that would aid our efforts in smoking cessation. Later, which is disappointing, we recalled that the smoking cessation brochures were covered in dust at the CHC. Thus, we obtained the permission to take some and eventually, we had the opportunity to help our patients. Evidently, the coordination between FHC and CHC was not flawless.

\section{Primary care in undergraduate medical education}

It is essential that medical education prepares the physician candidates to become more familiar with the PHC as well as policies and regulations pertaining to it. Primary care internship has a multifaceted role in developing future health professionals as providers, leaders, and advocates in health. However, its role in undergraduate education seems to be neglected.

After graduating from medical school, we are eligible to start working at primary care level; for this reason, we have to see ourselves as thoroughly qualified to do so. What we learn during this internship is also important in other levels of health care provision. We have seen that some FDs were prescribing expensive branded drugs rather than their generic alternatives, resulting in a higher financial burden for both individuals and society. We think that this is mainly because cost-effectivity and drug reimbursement policies are not taught at undergraduate level and rational pharmacotherapy skills of the new graduates are lacking. Therefore, the national core curriculum should draw clear goals and indicators for new graduates regarding health economics and health systems.

\section{Conclusion}

During our internship, we have experienced that special characteristics of the district that we work in impose limitations on PHC provision. There were some major shortcomings which limited the huge potential of PHC. These included: flawed coordination among FHCs and other level providers, suboptimal work environment and conditions including high number of patients per FD, underestimation of certain preventive services such as family planning and the need for better health information systems. We believe that PHC concepts should be emphasized in medical education to overcome these shortcomings and this should be undertaken through an effective partnership between academia, providers, policymakers, and patients. 


\section{Contribution of all authors:}

Kaymaz K: Conceived and designed the study, drafted the manuscript, and revised it critically for important intellectual content

Bilir E: Conceived and designed the study, drafted the manuscript, and revised it critically for important intellectual content

Conflict of Interest: No conflict of interest was declared by the authors.

Ethical Approval: Ethics committee approval was not required for this manuscript.

Financial Disclosure: The authors declared that this study received no financial support.

Acknowledgments: The authors would like to thank their faculty members at the Department of Public Health and the healthcare professionals from Family Health Center and Community Health Center.

\section{References}

1. World Health Organization, Regional office for Europe. Primary Care Evaluation Tool (PCET). http://www.euro.who.int/en/healthtopics/Health-systems/primary-healthcare/publications/2010/primary-careevaluation-tool-pcet. Published 2008.

2. Türkiye Cumhuriyeti Sağlık Bakanlığı. Sağlık İstatistikleri Yıllığı 2017. Ankara; 2018.

3. Kringos DS, Boerma WGW, Hutchinson A, Saltman RB. Building Primary Care in a Changing Europe - Case Studies.; 2015. doi:10.1002/we.193

4. Erdoğan MM. "Kopuş"tan "Uyum"a Kent Mültecileri- Suriyeli Mülteciler ve Belediyelerin Süreç Yönetimi: İstanbul Örneği; 2017. http://en.marmara.gov.tr/UserFiles/Atta chments/2017/05/09/2a50f712-6413489f-9deb-56dc52de7264.pdf.

5. Akman M, Sakarya S, Sargin M, et al. Changes in primary care provision in Turkey: A comparison of 1993 and 2012. Health Policy (New York). 2017;121(2):197-206. doi:10.1016/j.healthpol.2016.11.016 